\title{
Influence of rainfall and design criteria on performance of rainwater harvesting systems placed in different Brazilian climatological conditions
}

\section{Influência da precipitação e de critérios de projeto no desempenho de sistemas de aproveitamento de água chuva em diferentes condições climatológicas brasileiras}

\author{
Carla Fernanda Perius ${ }^{1}$ (D), Rutineia Tassi ${ }^{1}$ (D), Lucas Alves Lamberti ${ }^{2}$ (D), Angélica Guimarães da Silva ${ }^{1}$ (D) \&
} Liriane Élen Böck ${ }^{1}$ (D)

\author{
${ }^{1}$ Universidade Federal de Santa Maria, Santa Maria, RS, Brasil \\ ${ }^{2}$ Universidade Federal de Santa Maria, Cachoeira do Sul, RS, Brasil \\ E-mails: carlafperius@gmail.com (CFP),ruti@ufsm.br (RT), lucas.lamberti@ufsm.br(LAL), silva.angelicaguimaraes@gmail.com (AGS), liriane. \\ bock@gmail.com (LEB)
}

\begin{abstract}
Using rainwater harvesting (RWH) system is influenced by socioeconomic, environmental and technical factors. This work presents as analysis of the influence of the rainfall time series characteristics and design criteria on RWH performance of five Brazilian capitals with different climatic characteristic: Goiânia, João Pessoa, Manaus, Porto Alegre and São Paulo. The analysis combined different rooftop areas, storage volumes and the indoor and outdoor demands. Rainfall temporal discretization and the types of demands were the most important characteristics when assessing RWH reliability. Daily rainfall data were suitable for sizing the RWH, the time series length influenced the sizing of larger storage volumes, and the RWH efficiency was not significantly affected by the first-flush. Toilet flushing and the irrigation demands had the greatest impact on RWH performance. The greatest potentials for the implementation of RWH were observed for Porto Alegre, because of well distributed rainfall throughout the year, and for Manaus owing to higher annual volumes of precipitation. These results highlight relevant aspects that must be observed during the conception and design of RWH, complementing the guidelines provided in the Brazilian technical standards.
\end{abstract}

Keywords: Reliability; Feasibility; Demand; Design criteria.

\section{RESUMO}

Os sistemas de aproveitamento de água da chuva (RWH) são influenciados por fatores socioeconômicos, ambientais e técnicos. Foi avaliada a influência das características das séries temporais de chuva e dos critérios de projeto no desempenho de RWH em cinco capitais brasileiras com diferentes características climáticas: Goiânia, João Pessoa, Manaus, Porto Alegre e São Paulo. As análises combinaram diferentes áreas de telhado, volumes de armazenamento e demandas. As séries diárias de precipitação foram adequadas para dimensionar o RWH, a extensão da série influenciou a eficiência para maiores reservatórios, e a eficiência de RWH não foi significativamente afetada pelo first-flush. As demandas de descarga da bacia sanitária e irrigação tiveram o maior impacto no desempenho do RWH. Os maiores potenciais para a implantação de RWH foram observados para Porto Alegre, devido à precipitação bem distribuída ao longo do ano, e para Manaus devido aos maiores volumes anuais de precipitação. Esses resultados evidenciam aspectos relevantes que devem ser observados durante a concepção e projeto de RWH, complementando as diretrizes previstas nas normas técnicas brasileiras.

Palavras-chave: Confiabilidade; Viabilidade; Demanda; Critérios de projeto. 
Influence of rainfall and design criteria on performance of rainwater harvesting systems placed in different Brazilian climatological conditions

\section{INTRODUCTION}

The growing urban development generates greater pressure on water resources and the consequent concern with their management (Hoff, 2010; Arfanuzzaman \& Rahman, 2017; Connor et al., 2019; An et al., 2021). In this sense, the suitable water resources planning must consider the managing of demand as well introducing alternative sources for water supply (Hurlimann, 2011; McDonald et al., 2014; Fielding et al., 2015; Dean et al., 2016; Hurlimann \& Dolnicar, 2016). The rainwater is an alternative source of water, and its usage allows to increase water supply without the need of new sources of water and contributes to the reduction of water scarcity situations (Elliott \& Trowsdale, 2007; Palla et al., 2011; Kim \& Furumai, 2012; Rahman et al., 2012; Campisano et al., 2017; van Dijk et al., 2020; Semaan et al., 2020; Kahinda et al., 2010; Notaro et al., 2016), being a technique recently incorporated into the Marco Legal do Saneamento Básico Brasileiro (Brazilian Basic Sanitation Legal Framework), according to the Bill 3189/19 (Brasil, 2020). This strategy can assist Brazil to achieve the goal No. 6 of sustainable development (SDG-6), established by the United Nations, which deals with water and sanitation (Cardoso et al., 2020).

The use of rainwater is mainly intended for non-potable uses, as toilet and urinal flushing, vehicles and sidewalks washing, garden irrigation and landscaping, once the rainwater quality makes its unsuitable for drinking purposes without treatment (Associação Brasileira de Normas Técnicas, 2019). However, this does not diminish the importance of this practice, since more than $40 \%$ of the water consumption of a residence could be fully supplied by rainwater (U.S. Environmental Protection Agency, 2004; Muthukumaran et al., 2011; Campisano \& Modica, 2012; Campisano et al., 2017; Lopes et al., 2017). Additionally, the rainwater usage reduces the property's water bills and, some studies also suggest that the rainwater harvesting (RWH) may provide a local stormwater attenuation feature (Elliott \& Trowsdale, 2007; Memon et al., 2009; Sample \& Liu, 2014).

The planning of the RWH system is influenced by a series of socioeconomic, environmental and technical factors such as the rainfall regime, rainwater quality, space availability, required demands and its characteristics, criteria for project, among others (Santos \& Taveira-Pinto, 2013; Melville-Shreeve et al., 2016; MartínezAcosta et al., 2019; Vargas et al., 2019; Toosi et al., 2020). Therefore, it is difficult to find a basic and generic recommendation for the size and configuration of rainwater storage systems (Jones \& Hunt, 2010; Campisano et al., 2017; Corrêa et al., 2018; Semaan et al., 2020), especially in regions and countries, such as Brazil, where the large climatic variability can affect the RWH performance (Palla et al., 2012; Sahin \& Manioglu, 2019, Pacheco et al., 2017).

However, in Brazil, there has been technical standardization for RWH design since 2007 (Brazilian Technical Standard, NBR 15527), when the first guidelines for projects of this type of system in urban areas were presented (Associação Brasileira de Normas Técnicas, 2007). In the first version, different methodologies for sizing the volume of the storage tank were presented, although they could generate completely different required volumes, even when evaluated in the same climatic condition (Imteaz et al., 2012; Campisano \& Modica, 2016). In 2019, a revised version of the NBR 15527 was released, and the previous sizing methodologies were removed, remaining only the water mass balance model (Associação Brasileira de Normas Técnicas, 2019).

There is an international consensus that among the different possible methods for sizing the storage tank reservoirs, which include empirical relationships (Ghisi, 2010; Palla et al., 2011), stochastic analysis (Cowden et al., 2008; Basinger et al., 2010; Lopes et al., 2017), and the water mass balance model, the last one would be the most common (Fewkes \& Butler, 2000; Liaw \& Tsai, 2004; Campisano \& Modica, 2012; Zhang et al., 2019). This method allows to incorporate characteristics of rainfall and the dynamics of water demand, at different spatial-temporal scales (Herrmann \& Schmida, 1999; Liaw \& Tsai, 2004; Mitchell, 2007; Campisano \& Modica, 2015; Melville-Shreeve et al., 2016).

However, the NBR 15527 can be a quite generic and it is often necessary to observe technical guidelines available in the specialized literature (Mitchell, 2007; Helmreich \& Horn, 2009; Ward et al., 2010; Basinger et al., 2010; Mun \& Han, 2012). Despite that, even in these reports there are few recommendations regarding the system sizing and the uncertainties related to the RWH performance in different climatic regions, because most studies concentrated on the analysis of specific situations, considering the local rainfall regime while varying the roof area and water demand (Palla et al., 2012).

In this study the long-term water Mass Balance Method was used to assess how the reliability of the RWH is influenced by those aspects related to rainfall data availability and design criteria in cities with different climate conditions. Five Brazilian cities placed in different climate characteristics were selected for these analyzes. A set of rainfall data with different time series length, as well as rainfall data with different temporal discretization (hourly, daily and monthly) were evaluated during the analysis. Lastly the design criteria as the usage of a first-flush device and four different demands scenarios were also evaluated.

\section{METHODOLOGY}

\section{Cities and climatic conditions}

Five Brazilian state capitals located in different climate regions were used for this study: Goiânia (GO), João Pessoa (PB), Manaus (AM), Porto Alegre (RS) and São Paulo (SP) (Figure 1). According to Köppen-Geiger classification (Alvares et al., 2013), Goiânia has a Tropical Savanna Climate (Aw), with average temperature around $24.1^{\circ} \mathrm{C}$. Its average annual rainfall is $1559.6 \mathrm{~mm}$, with large amounts of rain from October to March (Figure 2a).

João Pessoa have a Tropical Monsoon Climate (Am), the average temperature is $26.8^{\circ} \mathrm{C}$ and the average annual rainfall is $1674.8 \mathrm{~mm}$, with large amounts from March to August in João Pessoa. Manaus has a Tropical Equatorial Climate (Af), with an average temperature of $27^{\circ} \mathrm{C}$ and average annual rainfall of $2302.8 \mathrm{~mm}$, and the rainy season is from December to May (Figure 2c).

Porto Alegre has a Humid Subtropical Climate (Cfa). In this city, the average temperature is $19.6^{\circ} \mathrm{C}$ and the average annual rainfall is $1397.6 \mathrm{~mm}$ well distributed throughout the 
A Study Cities Brazil States

Köppen climate classification

\section{A - Tropical zone}

Af - without dry season

Am - monsoon

Aw - with dry winter

As - with dry summer

\section{B - Dry zone}

Bs - semiarid

BSh - low latitude and altitude

\section{C - Humid subtropical zone}

$\mathrm{Cf}$ - oceanic climate, without dry season

Cfa - with hot summer

$\mathrm{Cfb}$ - with temperate summer

$\mathrm{Cw}$ - with dry winter

Cwa - and hot summer

Cwb - and temperate summer

Cwc - and short and cool summer

Cs - with dry summer

Csa - and hot

$\mathrm{Csb}$ - and temperate

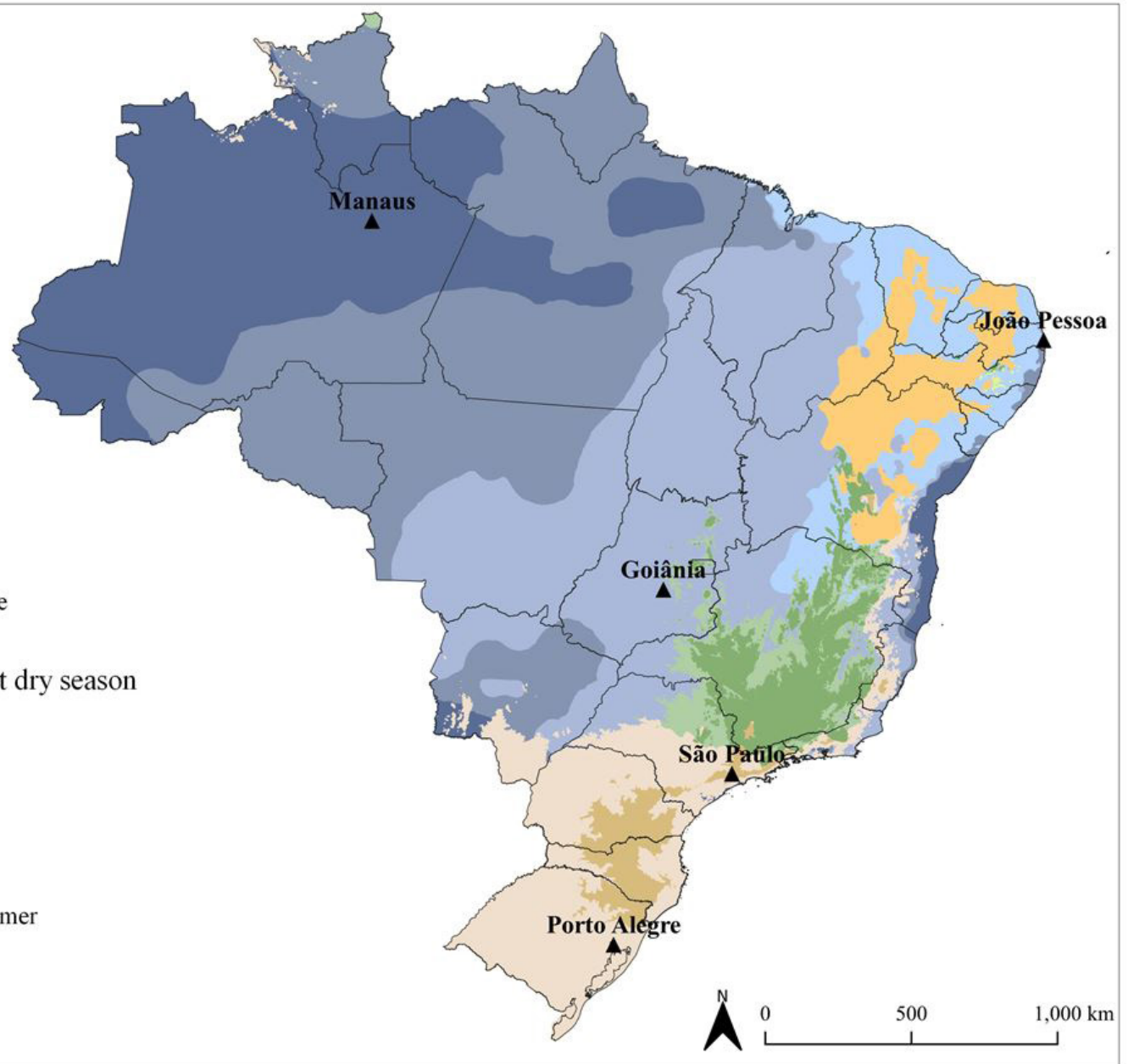

Figure 1. Brazilian cities evaluated.

year (Figure 2d). São Paulo has an Oceanic Climate (Cfb), with $1602.4 \mathrm{~mm}$ average annual rainfall and an average temperature of $20.1^{\circ} \mathrm{C}$. Whilst Porto Alegre and São Paulo have approximately the same amount of annual rainfall, in São Paulo most of this volume occurs from October to March (Figure 2e).

\section{Modeling and performance evaluation}

To achieve the main objectives, the strategy applied was based in long-term mathematical modeling evaluating different scenarios. To simulate the RWH system the Equations 1 and 2 based on water mass balance model were applied. The input data required are the rainfall, building related information as rooftop area and its runoff coefficient, rainwater demands and storage tank capacity. The simulation outputs are the rainwater supply failure rate, overflows, and the potential for potable water savings for every storage tank capacity evaluated.

$V_{(t+1)}=Q_{(t+1)}+V_{(t)}-D_{(t+1)}$, subject to $0 \leq V_{(t+1)} \leq S$

$Q_{(t+1)}=C \times P_{(t+1)} \times A$ being: $\mathrm{V}_{(\mathrm{t}+1)}$ the water (rainfall) in the storage tank at end of time interval, $t+1 ; \mathrm{V}_{(\mathrm{t})}$ the water (rainfall) in storage tank at end of time interval, $t ; \mathrm{D}_{(\mathrm{t}+1)}$ the water demand during time interval, $t+1$; $\mathrm{Q}_{(\mathrm{t}+1)}$ the inflow (stormwater runoff) during time interval, $t+1$; $\mathrm{C}$ the rooftop runoff coefficient; $\mathrm{P}_{(\mathrm{t}+1)}$ the total rainfall during time interval, $t+1$; A the rooftop superficial area; $\mathrm{S}$ the storage tank capacity.

For each scenario, a set of different rooftop areas $\left(100 \mathrm{~m}^{2}, 200 \mathrm{~m}^{2}\right.$ and $\left.300 \mathrm{~m}^{2}\right)$, commonly found in urban areas, and progressive commercial volumes for rainwater storage tank $\left(1 \mathrm{~m}^{3}, 1.5 \mathrm{~m}^{3}, 2 \mathrm{~m}^{3}, 3 \mathrm{~m}^{3}\right.$ e $\left.5 \mathrm{~m}^{3}\right)$ were assessed. Together with the rooftop runoff coefficient (0.95), those parameters were kept fixed throughout the simulations.

At the beginning of the simulation, the storage tank was set as full (maximum storage tank capacity), following the recommendation of Perius (2016), who identified little influence of this criterion on RWH performance. Additionally, it was considered that $100 \%$ of stormwater runoff is directly diverted to the storage tank, that both gutters and pipes have enough hydraulic capacity to convey the flows without overflowing, and that evaporation loses can be disregarded. Furthermore, additional sources of water supply were not contemplated during simulation. 


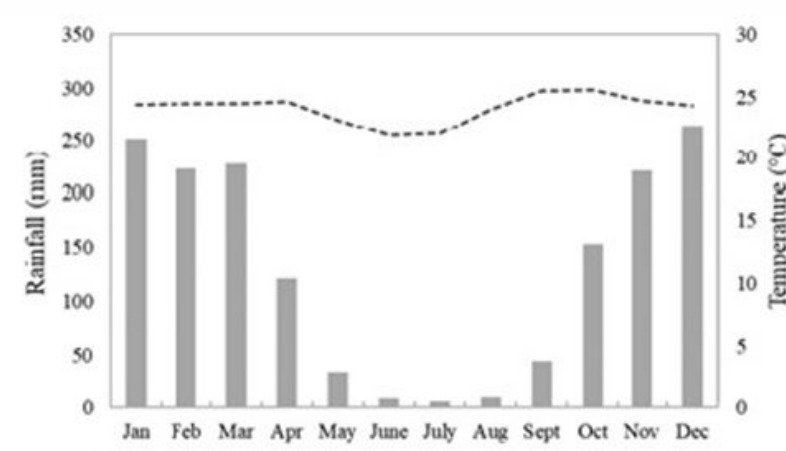

a) Goiânia

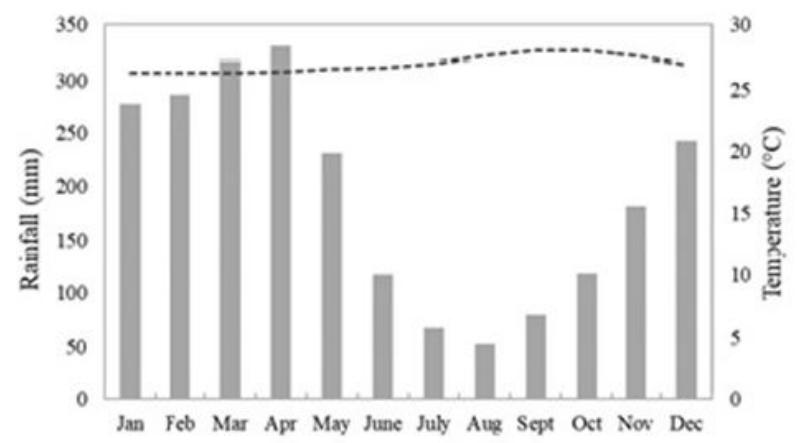

c) Manaus

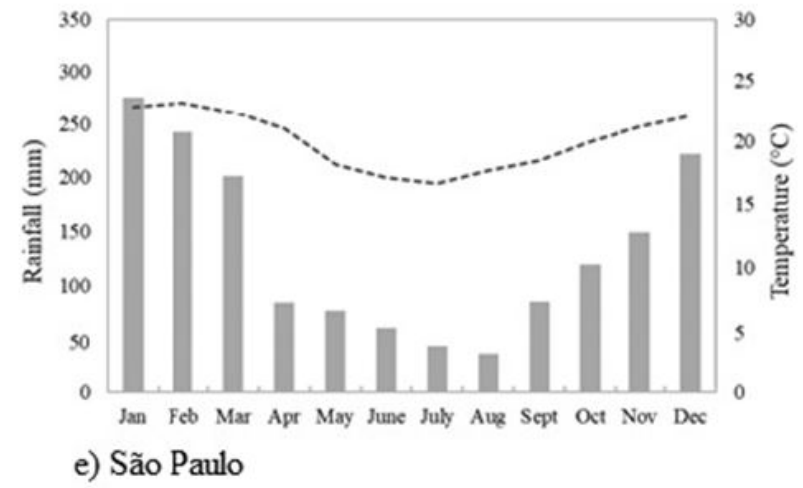

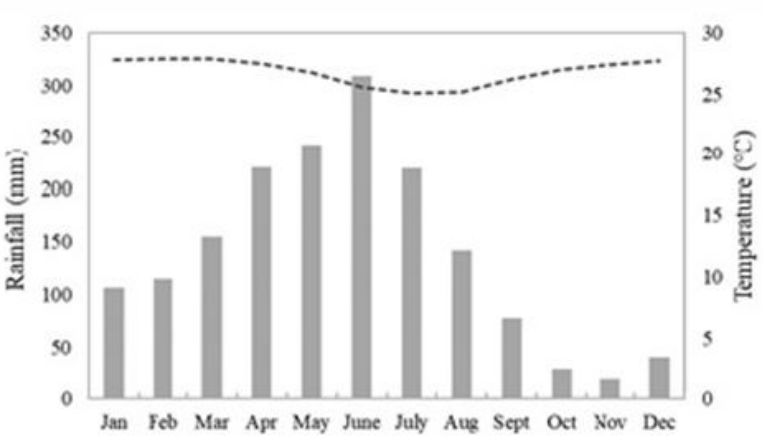

b) Joảo Pessoa

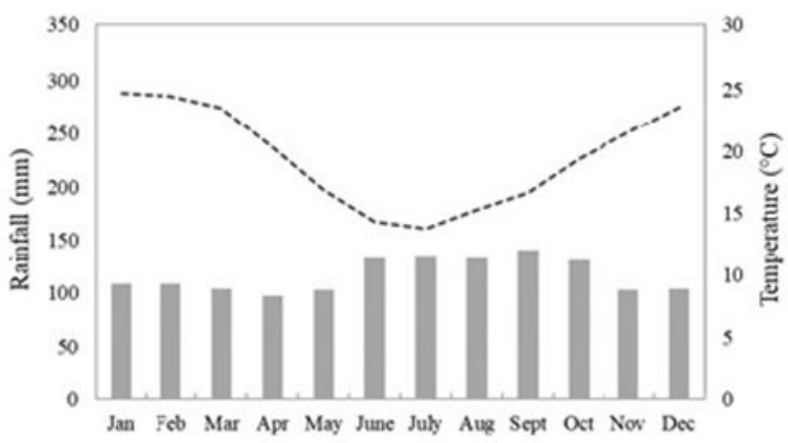

d) Porto Alegre

Figure 2. Average monthly rainfall and temperature in the five Brazilian Capitals studied.

The non-dimensional failure rate (Equation 3) was chosen as indicators to compare the results between cities and scenarios along the simulations.

$$
F R=\left(\frac{\sum_{t=1}^{T} D_{e f}}{\sum_{t=1}^{T} D_{e m}}\right) .100
$$

being: FR the failure rate; $\mathrm{D}_{\text {ef }}$ the total water deficit volume; $\mathrm{D}_{\mathrm{em}}$ the total water demand volume; $\mathrm{T}$ the $\mathrm{t}^{\mathrm{TH}}$ time-period.

\section{Scenarios}

Different simulation scenarios were defined, allowing an individual evaluation of the effect of each component to be investigated on the RWH performance. Hence, in a first stage, the effect of the rainfall temporal discretization used in the simulation was investigated in scenarios including hourly, daily, and monthly time intervals. Following, the influence of the rainfall time series length, the usage of the first-flush diverter and four possible rainwater demands scenarios were evaluated.

In order to compare the results between the simulations, the scenario initially adopted as a reference considered the first-flush device, supplying the demand 1 (D1) and hourly rainfall timestep - all detailed information about these criteria is appropriately presented in the following sections. However, as it will be seen in the first results related to the time-step analysis, the daily rainfall data proved to be suitable for RWH design, then the subsequent scenarios evaluated used the daily time-step as a reference, due to the longer rainfall time series available with this time-resolution. 
Therefore, this scenario was changed according to the analysis to be accomplished. In these cases, all parameters were kept fixed, except that one under evaluation.

The conditions to be investigated were combined with three different rooftop areas, five storage tank volumes and four demands (D1, D2, D3 and D4) in a total of 1050 simulations. Table 1 shows an overview of the investigated variables, which were combined to define the simulation scenarios. Data source and criteria are presented below.

\section{Rainfall data influence}

Hourly rainfall time series were freely obtained at INMET (Brazilian National Institute of Meteorology) database (Instituto Nacional de Meteorologia, 2016), as well the daily rainfall data were obtained at ANA (Brazilian National Water Agency) for each city evaluated (Table 2). Before usage, the time series were checked for consistency by using doble-mass analysis and missing data were identified.

Following recommendations from Perius (2016), when the missing hourly values along any year were greater than $30 \%$, the correspondent year was discarded, which happened for João Pessoa (2012 and 2015 were removed) and Manaus (2003, 2004, 2005 and 2009 were removed). Zero values were adopted when missing values were lower than $30 \%$. When missing daily values were reported, zero values were used for replacing them during 15 consecutive missing values, after that, the modeling was interrupted until the next valid data.

\section{Temporal discretization}

The result of water mass balance simulation carried out with Equation 1 can be affected by the modelling time-step, normally equal to the input time interval data (Campisano \& Modica, 2014). Thus, to evaluate the influence of time-step on RWH performance, 225 simulations were accomplished by using both rainfall and demand time series, according to the following temporal resolutions: i) hourly (reference scenario); ii) daily; and iii) monthly.

These temporal resolutions were also the time-step during simulations, which were accomplished for the five cities, with three different rooftop areas and the five storage tank volumes. During these analyses, the demand 1 (D1) was kept fixed and a chamber for first-flush diversion was used - detailed information about D1 and first-flush diversion are provided further in the text. The rainwater supply failure rate from daily and monthly scenarios were compared against the reference scenario failure rate (hourly).

\section{Time series length}

Long-term rainfall data are recommended for assessing RWH, and a 30-year time series is commonly considered as representative (World Meteorological Organization, 1989) for this analysis. However, meeting this requirement can be unfeasible due to the lack of long-term historical data, and short-term time series data are often the only source for the RWH project (Geraldi \& Ghisi, 2017; Zhang et al., 2020; Yue et al., 2020; Ali et al., 2020). Nevertheless, few studies (Ghisi et al., 2012; Geraldi \& Ghisi,

Table 1. Investigated variables on scenarios composition for evaluating RWH performance.

\begin{tabular}{ccccc}
\hline Rainfall time-step & First-flush treatment & Demand type & Rooftop areas $\left(\mathbf{m}^{2}\right)$ & $\begin{array}{c}\text { Storage tank volumes } \\
\left(\mathbf{m}^{3}\right)\end{array}$ \\
\hline & & D1 & 100 & 1.0 \\
Hourly & With diverter & D2 & 200 & 1.5 \\
Daily & Non-diverter & D3 & 300 & 2.0 \\
Monthly & & D4 & 3.0 \\
\hline
\end{tabular}

Table 2. Rainfall time series characteristics.

\begin{tabular}{|c|c|c|c|c|c|c|}
\hline \multirow[b]{2}{*}{ City } & \multicolumn{3}{|c|}{ INMET } & \multicolumn{3}{|c|}{ ANA } \\
\hline & $\begin{array}{l}\text { Rain Gauge } \\
\text { Station Code }\end{array}$ & $\begin{array}{l}\text { Begin-End } \\
\text { (Month/year) }\end{array}$ & $\begin{array}{c}\text { Hourly } \\
\text { time series } \\
\text { length } \\
\text { (years) }\end{array}$ & $\begin{array}{l}\text { Rain Gauge } \\
\text { Station Code }\end{array}$ & $\begin{array}{l}\text { Begin-End } \\
\text { (Month/year) }\end{array}$ & $\begin{array}{l}\text { Daily time series length } \\
\quad \text { (years }+ \text { month) }\end{array}$ \\
\hline Goiânia & $\mathrm{A} 002$ & $\begin{array}{l}\text { Jan/2002- } \\
\text { Dec/2015 }\end{array}$ & 14 & 01649013 & Jan/1949-Jun/2019 & $70+5$ \\
\hline João Pessoa & A 320 & $\begin{array}{l}\text { Jan/2008- } \\
\text { Dec/2015 }\end{array}$ & 8 & 734037 & $\begin{array}{l}\text { Jan/1996- } \\
\text { May/2018 }\end{array}$ & $22+4$ \\
\hline Manaus & A101 & $\begin{array}{l}\text { Jan/2001- } \\
\text { Dec/2015 }\end{array}$ & 15 & 359005 & Jul/1997-nov/2019 & $22+4$ \\
\hline Porto Alegre & A801 & $\begin{array}{l}\text { Jan/2001- } \\
\text { Dec/2015 }\end{array}$ & 15 & 03051011 & Jan/61-jun/2019 & $58+5$ \\
\hline São Paulo & A701 & $\begin{array}{l}\text { Jan/2007- } \\
\text { Dec/2015 }\end{array}$ & 9 & 2346117 & Jun/1975-jun/2019 & $44+5$ \\
\hline
\end{tabular}


2019) have researched its real impact on the performance of these facilities in Brazilian cities, especially by comparing the results in different climate conditions.

Thus, a set of 375 simulations were carried out considering shorter rainfall time series than the original ones, with periods that were reduced every 5 years, always from the most recent to the oldest date. According to the length of the original series, new series with different extensions resulted for each city as presented in Table 3. Notice that even using the original time series from Manaus and João Pessoa the available length does not meet the recommendations from the World Meteorological Organization (WMO).

The different rainfall time series presented in Table 3 were assessed, with three different rooftop areas and five storage tank volumes for each city. The scenario with the original rainfall time series was considered as the reference, besides keeping the firstflush diverter and demand D1 fixed.

\section{Design criteria influence}

The influence of design criteria as the rainwater demand time series and the inclusion of the first-flush diversion on RWH performance was also evaluated by considering the following analysis.

\section{Demand time series influence}

The influence of the rainwater demand characteristics on RWH performance was evaluated by simulating four demand time series (D1, D2, D3 and D4), based on water consumption metering:

- D1: indoor and outdoor uses, including toilet flushing, garden irrigation, car washing and cleaning external areas;

- D2: indoor use for toilet flushing;

- D3: outdoor uses, including garden irrigation, car washing and cleaning external areas;

- D4: outdoor use for garden irrigation.

Brazilian average consumer demand patterns were considered for the establishment of these demands time series. In this light, 5 inhabitants per building was kept fixed, resulting in specifics rooftop area of $20 \mathrm{~m}^{2}$.person ${ }^{-1}\left(100 \mathrm{~m}^{2}\right), 40 \mathrm{~m}^{2} \cdot$ person $^{-1}\left(200 \mathrm{~m}^{2}\right)$ and $60 \mathrm{~m}^{2}$.person ${ }^{-1}\left(300 \mathrm{~m}^{2}\right)$, and the non-potable volumes were considered as: i) toilet flushing (6 L.flushing $\left.{ }^{-1}\right)$; ii) garden irrigation

Table 3. Evaluated rainfall time series length.

\begin{tabular}{ll}
\hline \multicolumn{1}{c}{ City } & \multicolumn{1}{c}{ Length } \\
\hline Goiânia & 5 years; 10 years; 15 years; 20 years; 25 years e 30 \\
& years \\
João Pessoa & 5 years; 10 years; 15 years e 20 years \\
Manaus & 5 years; 10 years; 15 years \\
Porto Alegre & 5 years; 10 years; 15 years; 20 years; 25 years e 30 \\
& years \\
São Paulo & $\begin{array}{l}5 \text { years; } 10 \text { years; } 15 \text { years; } 20 \text { years; } 25 \text { years e } 30 \\
\text { years }\end{array}$ \\
\hline
\end{tabular}

(0.19 $\mathrm{m}^{3}$.use $\left.\mathrm{e}^{-1}\right)$; iii) car washing $\left(0.22 \mathrm{~m}^{3} . \mathrm{use}^{-1}\right)$; and iv) cleaning external areas $\left(0.28 \mathrm{~m}^{3}\right.$.use $\left.\mathrm{u}^{-1}\right)$.

These demands were hourly-related, following water consumption metering typically found in the studied cities additional information about water consumption patterns are available in Hentges (2013). For time-steps modeling greater than the daily one the volumes were added according to the proper timescale. During simulations it was considered an average of 4 toilet flushes $\left(\right.$ day $^{-1} \cdot$ person $\left.^{-1}\right)$, and a biweekly cleaning external areas and car washing.

Drought period and the air temperature were considered to assess the garden irrigation demand. Therefore, the irrigation was considered every two days whether air temperature was higher than $20^{\circ} \mathrm{C}$ and the amount of rainfall during this period was equal zero. Otherwise, when temperature was lower than $20^{\circ} \mathrm{C}$, garden irrigation was computed weekly since the amount of rainfall during this period was zero.

A set of 300 simulations was accomplished, with three different rooftop areas, five storage tank volumes, five cities, and four rainwater demands. The failure rates from the D2, D3 e D4 demands were compared against D1 failure rate, considered as a reference scenario.

\section{First-flush diverter influence}

Filters and first-flush diverter can improve rainwater quality prior storage; however, the use of this device can reduce the amount of water stored and consequently the RWH performance for the same storage tank volume (Amin et al., 2013).

The influence of the first-flush deviation was evaluated through 150 simulations by comparing the performance between the RWH systems with and without the device. As a reference value, the initial $2 \mathrm{~mm}$ rainfall volume was considered for designing the diversion chamber, as recommended by the NBR 15527. Therefore, storage chambers with suitable volumes for the rooftop area $\left(200 \mathrm{~L}-100 \mathrm{~m}^{2}, 400 \mathrm{~L}-200 \mathrm{~m}^{2}\right.$ and $600 \mathrm{~L}-300 \mathrm{~m}^{2}$ ) were included in the modeling.

A weekly emptying was considered as a criterion for emptying the diversion chamber. The analyzes were accomplished for the three different rooftop areas, five commercial storage tanks and five cities analyzed to supply the D1 demand.

\section{RESULTS AND DISCUSSION}

\section{Rainfall data influence}

\section{Temporal discretization}

Figure 3 shows the RWH failure rate (FR), when the different rainfall temporal discretization are evaluated - this figure shows results for a $200 \mathrm{~m}^{2}$ rooftop area, because the results are similar for the additional rooftop area evaluated. The demand D1 and first-flush device was considered during this analysis. 
Overall, when considering the same city, the same rooftop area and demand, by increasing the rainfall temporal discretization, there is a reduction in demand-supply failures for the same storage tank volume. The differences found are less evident $(<20 \%)$ between the daily and hourly results, especially as the storage tank volume is increased.

The use of daily rainfall would lead to a storage tank undersized in approximately $6 \%$, when compared to the storage tank design based on hourly rainfall. Likewise, Campisano \& Modica (2014) evaluated that the differences between the storage tank volume designed with sub-hourly (five-minutes) and daily time series can reach up to $17 \%$. In this study, sub-hourly rainfall was not assessed due to the lack of available long-term rainfall data for all cities.

Corrêa et al. (2018) also suggest that when daily rainfall data are replaced by the sub-daily ones, the RWH storage tank volume can be oversized, especially when the first-flush volume is automatically discarded. During the simulations accomplished in this study, a weekly frequency of manual emptying of the first-flush chamber was considered, therefore, this effect was not observed.

Taking advantage of the approximate FR obtained by using daily and hourly rainfall data, a RWH failure correction factor $(\mathrm{Fc})$ is proposed, allowing to estimate the percentual of failure on rainwater demand supply that would be found whether an hourly rainfall time series is replaced by a daily one. Table 4 shows the values found for the cities and evaluated rooftop areas
It was not possible to estimate similar Fc values for monthly rainfall based on hourly data, due to the lack of a pattern for the different storage tank volumes and rooftop areas.

The monthly time interval produced an underreporting in the number of failures in demand-supply (decreasing from $20 \%$ to $35 \%$ ), practically invariable even when the storage tank volume is increased. Imteaz et al. (2012) also pointed out that the storage tank volume can be up to 1.6 times smaller than necessary when the RWH systems are designed by using monthly rainfall. It is noteworthy that in the NBR 15527 (Associação Brasileira de Normas Técnicas, 2019) monthly temporal discretization and even annual rainfall are suggested for designing the RWH system, which could lead to an undersized tank storage volume.

The analysis accomplished indicated that daily rainfall time series are suitable for RWH system design in the evaluated cities and were also adequate for Belém, State of Pará, Brazil (Corrêa et al., 2018). The use of daily rainfall time series is also an international recommendation, as stated by Campisano et al. (2017).

The suitability of daily rainfall data for RWH design allows to expand the range of available information, since the number of non-recording rain gauges in the Brazilian network managed by the National Water Agency (ANA) is much broader than the recording ones. Furthermore, daily time series are normally longer than hourly ones as presented in Table 2, having a better longterm representativeness. For this reason, the following analysis are presented solely for the simulations accomplished by using the daily rainfall time series.

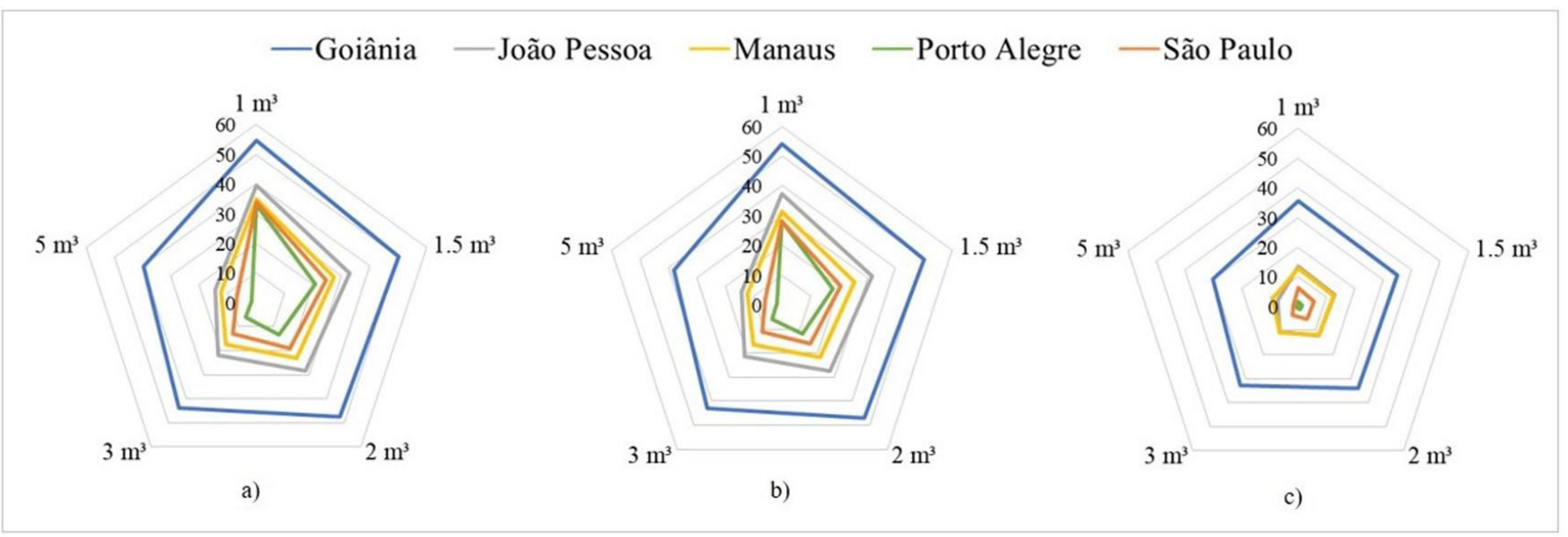

Figure 3. Failure (\%) of the RWH on demand-supply for rainfall temporal discretization (a) hourly; (b) daily; and (c) monthly - 200 $\mathrm{m}^{2}$ rooftop area.

Table 4. RWH failure correction factor $(\mathrm{Fc})$ for estimating failures (\%) on rainwater demand supply when hourly rainfall data are replaced by daily ones.

\begin{tabular}{cccccc}
\hline & Porto Alegre & São Paulo & Goiânia & João Pessoa & Manaus \\
\hline $100 \mathrm{~m}^{2}$ & 1.05 & 1.13 & 1.01 & 1.02 & 1.04 \\
$200 \mathrm{~m}^{2}$ & 1.10 & 1.18 & 1.02 & 1.05 & 1.06 \\
$300 \mathrm{~m}^{2}$ & 1.15 & 1.19 & 1.05 & $\mathbf{1 . 0 3}$ & 1.07 \\
Average & 1.10 & 1.17 & $\mathbf{1 . 0 2}$ & 1.10 \\
\hline
\end{tabular}


Time-series length

Table 5 shows the variability in the FR to meet D1 related to different rainfall time series length - results are presented for $200 \mathrm{~m}^{2}$ rooftop area, because other evaluated areas had similar behavior.

The FR due to shorter rainfall time series tend to be like the results obtained for the original rainfall time series length as suggested by Geraldi \& Ghisi (2017). Goiânia and São Paulo presented little variability in the $\mathrm{FR}$, when evaluating rainfall series shorter than the original one, and non-pattern of increasing or reducing the FR was observed due to rainfall time series length reduction. When considering the same storage tank volume, low coefficients of variation $(C v<3.1 \%)$ on FR were obtained for the different rainfall time series length from Goiânia. In the case of São Paulo, the coefficients of variation ranged from $1.5 \%\left(1 \mathrm{~m}^{3}\right)$ to $9.6 \%\left(5 \mathrm{~m}^{3}\right)$.

Similarly, Porto Alegre presented a non-defined pattern in the increasing or reducing FR due to different rainfall series length. However, when the rainfall time series is reduced from 58 years (original) to a shorter period evaluated ( 5 years), the FR is reduced by about $67 \%$ for a $5 \mathrm{~m}^{3}$ storage tank. In addition, Porto Alegre was the city that had the highest $C v$ for the same storage tank volumes, ranging from $3.6 \%\left(1 \mathrm{~m}^{3}\right)$ to $50 \%\left(5 \mathrm{~m}^{3}\right)$.

On other hand, in João Pessoa as shorter the rainfall time series lower the FR for all the storage tank volumes tested (Table 5). In addition, greater variation coefficients were obtained for FR as the storage tank volumes increased from $1 \mathrm{~m}^{3}(C v=$ $7.2 \%)$ to $5 \mathrm{~m}^{3}(C v=19.3 \%)$. In opposition, Manaus had the FR increased for shorter rainfall time series. Generally, the FR variation coefficient increased as the storage tank volumes were increased, varying from $11.5 \%\left(1 \mathrm{~m}^{3}\right)$ to $19.2 \%\left(5 \mathrm{~m}^{3}\right)$.

Therefore, the use of shorter rainfall time series does not necessarily cause an increase in the FR for the same storage tank volumes, as the result obtained for the cities of Porto Alegre and João Pessoa. For these cities, shorter time series generated a FR reduction, which could lead to an undersized storage tank for meeting the demand supply equivalent to that one that would be

Table 5. Failure (\%) of the RWH on demand supply according to different rainfall time series length.

\begin{tabular}{|c|c|c|c|c|c|c|}
\hline City & Series length & $1 \mathrm{~m}^{3}$ & $1.5 \mathrm{~m}^{3}$ & $2 \mathrm{~m}^{3}$ & $3 \mathrm{~m}^{3}$ & $5 \mathrm{~m}^{3}$ \\
\hline \multirow[t]{8}{*}{ Goiânia (\%) } & 5 years & 41.16 & 37.55 & 35.08 & 31.91 & 26.66 \\
\hline & 10 years & 42.18 & 38.46 & 35.86 & 32.88 & 28.17 \\
\hline & 15 years & 42.71 & 39.04 & 36.50 & 33.47 & 29.24 \\
\hline & 20 years & 42.68 & 39.06 & 36.42 & 33.21 & 29.04 \\
\hline & 25 years & 42.54 & 38.72 & 36.08 & 32.83 & 28.65 \\
\hline & 30 years & 41.99 & 38.02 & 35.29 & 31.95 & 27.84 \\
\hline & Original & 42.62 & 38.54 & 35.78 & 32.42 & 28.25 \\
\hline & $C v$ & 1.32 & 1.42 & 1.49 & 1.84 & 3.06 \\
\hline \multirow[t]{6}{*}{ João Pessoa (\%) } & 5 years & 24.34 & 18.26 & 14.59 & 10.61 & 6.57 \\
\hline & 10 years & 26.96 & 21.26 & 17.59 & 12.90 & 8.66 \\
\hline & 15 years & 28.29 & 23.03 & 19.62 & 15.41 & 10.54 \\
\hline & 20 years & 28.50 & 23.16 & 19.56 & 15.35 & 10.51 \\
\hline & Original & 29.40 & 23.82 & 20.17 & 15.76 & 10.87 \\
\hline & $C v$ & 7.16 & 10.27 & 12.53 & 15.81 & 19.30 \\
\hline \multirow[t]{5}{*}{ Manaus (\%) } & 5 years & 28.30 & 20.03 & 15.11 & 9.63 & 5.15 \\
\hline & 10 years & 24.04 & 16.86 & 12.29 & 7.17 & 3.75 \\
\hline & 15 years & 22.80 & 16.24 & 11.95 & 7.05 & 3.67 \\
\hline & Original & 22.03 & 15.78 & 11.75 & 6.94 & 3.46 \\
\hline & $C v$ & 11.51 & 11.15 & 12.29 & 16.82 & 19.23 \\
\hline \multirow[t]{8}{*}{ Porto Alegre (\%) } & 5 years & 25.45 & 15.76 & 9.52 & 4.16 & 0.55 \\
\hline & 10 years & 25.98 & 16.15 & 9.94 & 4.22 & 0.60 \\
\hline & 15 years & 26.61 & 16.62 & 10.38 & 4.36 & 0.56 \\
\hline & 20 years & 25.50 & 15.80 & 9.85 & 4.17 & 0.56 \\
\hline & 25 years & 26.05 & 16.34 & 10.40 & 4.54 & 0.79 \\
\hline & 30 years & 25.84 & 15.99 & 9.97 & 4.24 & 0.72 \\
\hline & Original & 28.18 & 18.40 & 12.30 & 5.83 & 1.62 \\
\hline & $C v$ & 3.59 & 5.59 & 8.85 & 13.30 & 49.85 \\
\hline \multirow[t]{8}{*}{ São Paulo (\%) } & 5 years & 35.24 & 26.94 & 22.36 & 16.59 & 11.26 \\
\hline & 10 years & 35.23 & 27.40 & 22.92 & 16.70 & 10.43 \\
\hline & 15 years & 35.35 & 26.98 & 22.44 & 16.56 & 10.51 \\
\hline & 20 years & 35.86 & 27.85 & 23.04 & 16.81 & 10.57 \\
\hline & 25 years & 35.26 & 27.34 & 22.42 & 16.22 & 9.80 \\
\hline & 30 years & 34.21 & 25.91 & 21.05 & 14.96 & 8.78 \\
\hline & Original & 34.62 & 26.45 & 21.28 & 14.91 & 8.70 \\
\hline & $C v$ & 1.52 & 2.39 & 3.45 & 5.10 & 9.62 \\
\hline
\end{tabular}


obtained by using the complete rainfall time series. The opposite problem would occur for other capitals, where storage volumes could be overestimated.

The lowest storage tank volumes remained with the highest FR for all evaluated rainfall series length. However, the greater storage tank volumes were the most affected by the rainfall time series length as indicated by the $C v$. For the city of Manaus, for example, by reducing the length of the original rainfall series from 22 years to 5 years, the percentual increase in the original FR reached $49 \%\left(5 \mathrm{~m}^{3}\right)$.

The variability of results found for the evaluated cities due to short rainfall time series corroborates with findings from different authors and locations around the world. Immich Júnior (2013), for instance, found that the use of short ( $<5$ years) rainfall time series from Porto Alegre could underestimate the RWH efficiency of a $20 \mathrm{~m}^{3}$ reservoir by up to $8 \%$, when compared to a 48-year series. Still, such author highlights that as the rainfall time series is increased from 20 years to 30 years, the differences in FR become smaller.

Geraldi \& Ghisi (2018) suggested a minimum 6-year rainfall time series for Santo Amaro city (close to São Paulo city) and a 15-year series for Santarém (close to Manaus) as suitable for RWH design, when long rainfall time series are unavailable. Those results agree with the findings in the present study about the need for longer time series for Manaus than for São Paulo aiming to reducing the uncertainties in the sizing storage tank volume. Otherwise, Mitchell (2007) reported that the use of a 10 -year rainfall data, compared to a 50-year rainfall data, did not diminish the accuracy of RWH performance for different cities in Australia, and Geraldi \& Ghisi (2017) suggest that short rainfall time series were especially important when assessing higher rainwater demands in Berlin.

Therefore, in a country like Brazil, with great climatic diversity, it is possible that there is not a single recommendation for the minimum rainfall time series length to be used in the RWH design. In this case, it is possible that the use of regional recommendations related to the minimum length of the rainfall time series be the most appropriate, and the technical standard could incorporate these advices, as already discussed by Campisano et al. (2017). Alternatively, when only short-term rainfall time series are available, or even when the only information are monthly data, stochastic weather generators are useful for creating daily rainfall data, minimizing the database extension problem (Cowden et al., 2008). Furthermore, the stochastic approach can help designers to better access the RWH storage capacity without the need for extremely long rainfall data periods (Lopes et al., 2017).

\section{Design criteria}

\section{First-flush diverter}

From Figure 4 it is possible to observe that for the same storage tank volume, the failures on demand-supply are greater when the first-flush diverter is considered by comparing with a non-diverter system, agreeing with results presented by Corrêa et al. (2018) and Semaan et al. (2020). Specifically, for the $200 \mathrm{~m}^{2}$ rooftop area, the introduction of a first-flush diverter means to discard a volume that can reach $0.4 \mathrm{~m}^{3}$ every 7 days. Results of this analysis

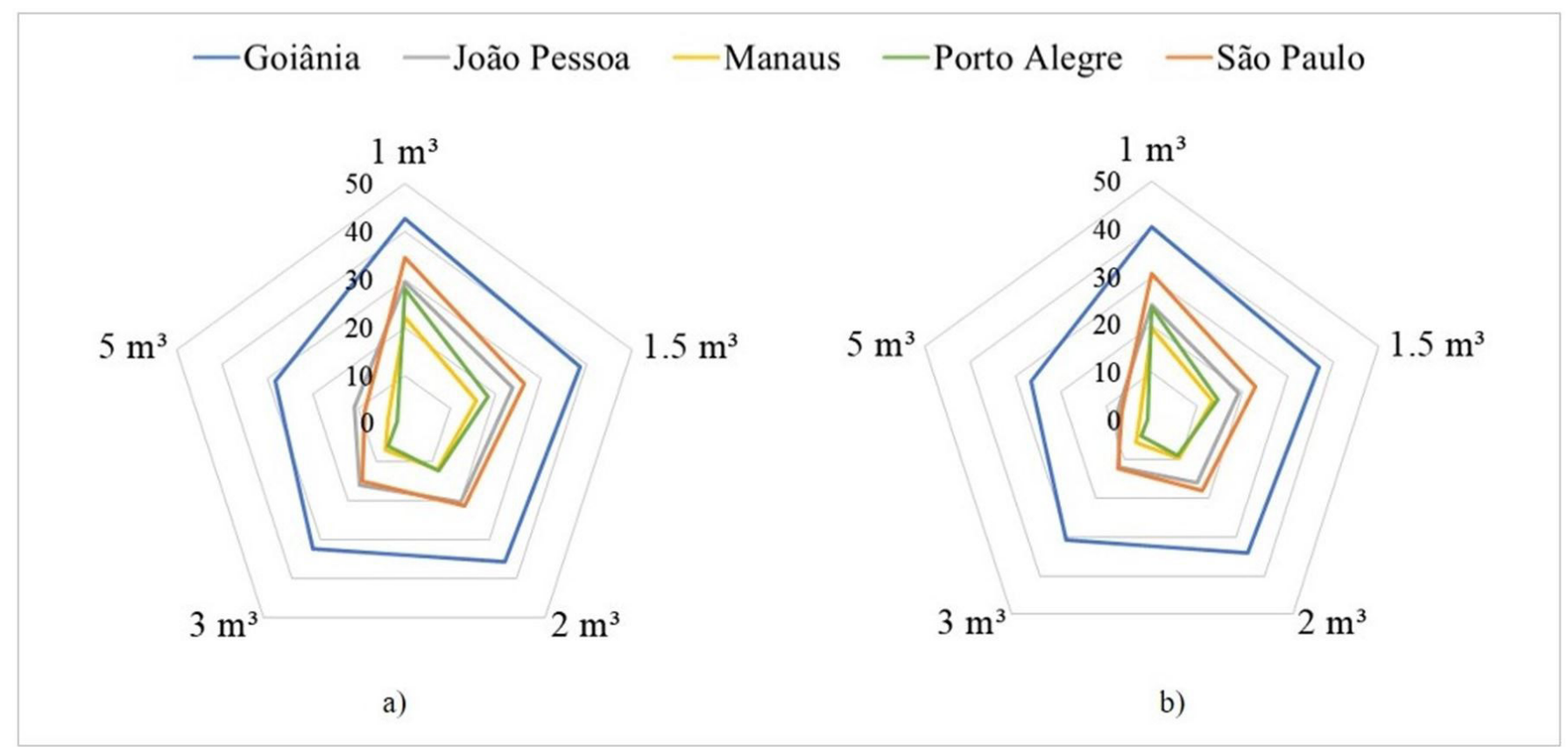

Figure 4. Influence of the first-flush diverter on FR (\%) on demand-supply: (a) with first-flush diverter; and (b) without first-flush diverter - $200 \mathrm{~m}^{2}$ rooftop area. 
are presented only for the $200 \mathrm{~m}^{2}$ rooftop area once the results for the other areas $\left(100 \mathrm{~m}^{2}\right.$ and $\left.300 \mathrm{~m}^{2}\right)$ follow the same pattern.

The first-flush diverter affected the RWH performance specially for the smallest storage tank volumes, due to the maintenance of a fixed diverter chamber volume (exclusively dependent on the rooftop area), even when the storage tank volume is increased. Percentual differences between FR of a system with first-flush diverter and a non-diverter system are presented in Table 6 . In this table, maximum and minimum percentual differences are related to $1 \mathrm{~m}^{3}$ and $5 \mathrm{~m}^{3}$ storage tanks, respectively. In any case, the difference does not exceed $5.1 \%$, which is a low value when considering other sources of uncertainties.

The major interference on FR due to the usage of a firstflush diverter chamber was observed in João Pessoa. Manaus

Table 6. Percentual differences between FR of a first-flush diverter and non-diverter RWH system.

\begin{tabular}{ccc}
\hline City & Maximum (\%) & Minimum (\%) \\
\hline Goiânia & 2.00 & 1.53 \\
João Pessoa & 5.09 & 3.43 \\
Manaus & 2.74 & 0.68 \\
Porto Alegre & 4.39 & 0.69 \\
São Paulo & 3.94 & 2.02 \\
\hline
\end{tabular}

and Porto Alegre presented lower interference of this criteria, especially for the greater storage tank evaluated, possibly due to the high amount of annual rainfall in the first city and due to a well distribution of the rainfall over the months in Porto Alegre. In the case of Goiânia, in the worst situation the difference is only $2 \%$ $\left(1 \mathrm{~m}^{3}\right)$, because of the winter months (May to September) which present the lowest rainfall volume, with precipitation almost nil.

Demand time-series

From Figure 5, it is possible to see that all simulated cities follow the same pattern regarding failures in meeting demands (results shown for $200 \mathrm{~m}^{2}$ rooftop area, as the other results are similar), and that D1 generated the highest FR in all cities.

Porto Alegre and Manaus have the lowest percentage of FR for all simulated combinations (rooftop areas, storage tank volumes and adopted demands) when compared to the other cities. Although Manaus presents a strong seasonal component in the distribution of rainfall, all months are rainy, and the city has the highest average annual rainfall (above $2300 \mathrm{~mm}$ ) among the evaluated cities. These characteristics ensure a good reliability on meeting the demands requirement. In the case of Porto Alegre,

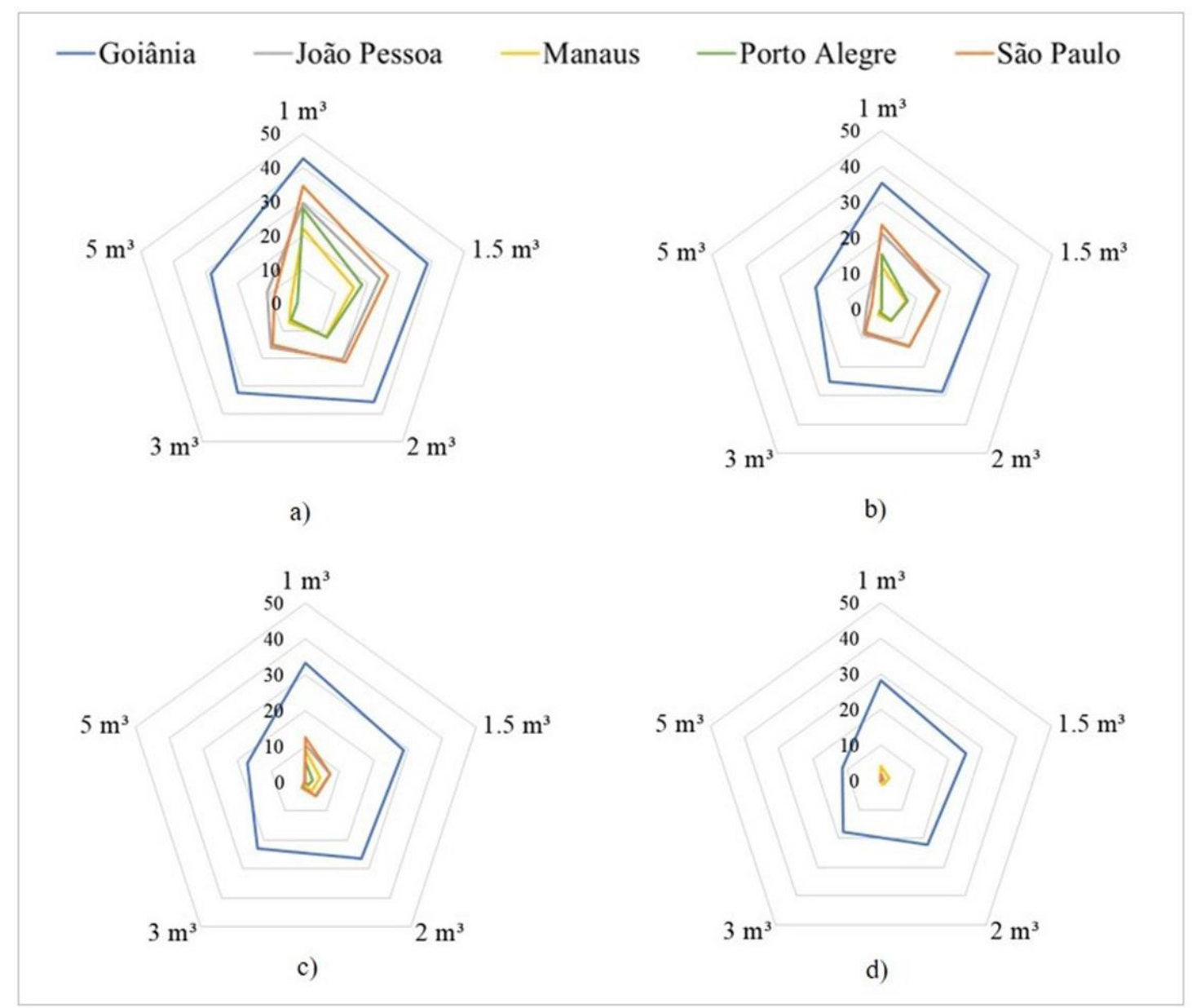

Figure 5. Effect of different rainwater demand time series on FR (\%): (a) Demand 1; (b) Demand 2; (c) Demand 3; (d) Demand $4-200 \mathrm{~m}^{2}$ rooftop area. 
although it is the capital city evaluated with the lowest average annual precipitation volume $(1397.6 \mathrm{~mm})$, all the demands assessed were also met with low FR, due to the good distribution of rainfall throughout the year.

The importance of a good temporal distribution of precipitation is more evident if observed that the highest percentages of failures in meeting any of the assessed demands were reported for Goiânia, although this city has an average annual rainfall higher than Porto Alegre. In this case, the period between June and August, in which the rainfall volumes are practically nil, ends up significantly compromising the performance of the RWH (Figure 6) for any demand assessed. Therefore, in regions where the rainfall pattern is like that observed in Goiânia, a poorly designed tank will result in a high failure rate or an oversized tank that is idle most of the time (Lopes et al., 2017). In these cases, the RWH reliability is limited by climate conditions, even when lower demands or higher rooftop area are considered (Imteaz et al., 2013).

Nevertheless, it is observed that among the evaluated demands the toilet flushing represents the consumption that has the greatest impact on RWH performance (Figure 5), a fact that can also be observed in Figure 6. Zhang et al. (2019) similarly reported that the indoor demands were the most cause for increasing

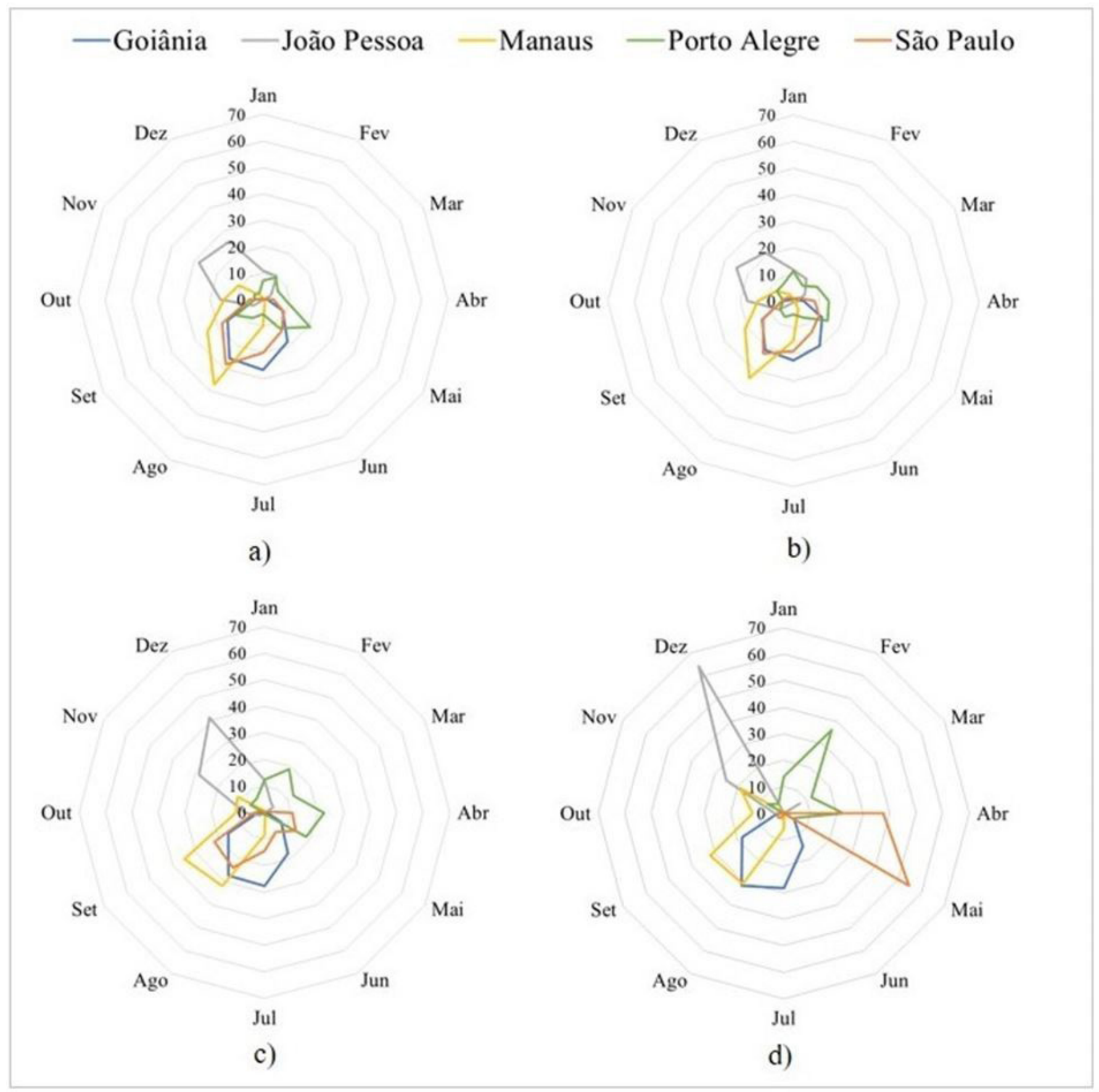

Figure 6. Average monthly FR (\%) variability: (a) Demand 1; (b) Demand 2; (c) Demand 3; (d) Demand 4 - $200 \mathrm{~m}^{2}$ rooftop area. 
Influence of rainfall and design criteria on performance of rainwater harvesting systems placed in different Brazilian climatological conditions

RWH failures when assessing four Chinese cities. Figure 6a and Figure 6b show that FR in meeting D1 and D2 are practically uniform over the months - rooftop areas of $200 \mathrm{~m}^{2}$ and the five storage tank volumes evaluated.

The temporal invariable characteristic of the demand for toilet flushing throughout the year implies in needs for constant rainwater availability. This result is more evident when comparing Figure $6 \mathrm{a}$ and Figure $6 \mathrm{~b}$ with Figure $6 \mathrm{c}$ for meeting D3, in which the only difference is the removal of the toilet flushing. In this case, the FR are concentrated in the lowest rainfall months, especially influenced by the garden irrigation demand (D4). Figure 6d shows exclusively this kind of demand that is specially controlled by the temperature, and strongly influences the results for Porto Alegre, which have the highest thermal amplitude throughout the year. For Porto Alegre the FR are more accentuated in the period from November to May, when the average temperatures are above $20^{\circ} \mathrm{C}$ and the monthly rainfall is a little lower. D4 generated the smallest FR for any storage tank volume evaluated, and for João Pessoa, Porto Alegre and São Paulo these values varied between $2 \%$ and $0 \%$. For Manaus, FR are below $5 \%$, reaching $0 \%$ for the $5 \mathrm{~m}^{3}$ storage tank. For the city of Goiânia, the use of rainwater only for garden irrigation contributes to the reduction of FR, although this criterion was not as effective in reducing the FR as in other cities.

The most critical conditions evaluated were related to high seasonality in the rainfall regime, months with low amount of rain, and consecutive rainless periods, corroborating with Zhang et al. (2019) and Lopes et al. (2017). In addition, high rainwater demands compromises the RWH performance and the $100 \%$ reliability is not achievable even with a large rooftop size and a big tank volume (Imteaz et al., 2013).

Thus, the rainwater demands can be optimized according to the local climatic characteristics. In Goiânia, for instance, RWH can be designed for meeting specific demands which are coincident with the rainy season, otherwise, the efficiency of the system can be greatly reduced. In addition, it is noticed that the incompatibility of the RWH system is highest when the greatest demand for irrigation coincides with the summer period, when the lowest rainfall levels are usually concentrated. Therefore, seasonal demands strongly influenced by climatic conditions can result in less reliability in RWH systems (Mitchell et al., 2008).

\section{CONCLUSION}

In this article, the performance of the RWH was evaluated for five Brazilian capitals, with different climatic characteristics, which include average annual precipitation, seasonality and temperatures. It was investigated how the percentage of failures in meeting rainwater demand is affected by rainfall-related information, such as the temporal discretization and time series length, besides design criteria such as types of rainwater demands and the use of first-flush diverter system.

Regarding the temporal discretization of the rainfall data, the best results were obtained with a sub-daily temporal discretization. However, given the greater availability of daily precipitation data in the Brazilian monitoring network, in addition to a greater extension of this database, daily information can be used to replace the sub-daily data, with reliable results. On the other hand, the designing of RWH with monthly time series is not encouraged, because they can considerably underestimate the storage volumes.

The rainfall time series length caused a great variability on RWH performance results, which can partly be explained by the statistics of the time series period used in each analysis. In any case, longer rainfall time series reduced the uncertainties in the results. Therefore, it is recommended to use representative time series, or even the introduction of modeling that includes stochastic components and climate change forecast to assess the long-term reliability of RWH.

No major losses in the RWH efficiency were observed due to the use of a first-flush diverter system, with the maximum difference of $5 \%$ compared to a system without first-flush diverter. Besides low influence on the final performance of the RWH system, the introduction of this device ensures that the stored water has better quality, reducing maintenance frequency and costs.

The characteristics of the demand series significantly influenced the RWH performance, thus deserving special attention. Indoor usage such as toilet flushing, for instance, is a type of demand characterized by invariability throughout the year, independently on temperature or rainfall. Therefore, cities placed in regions with rainfall volume well distributed throughout the year have great potential to meet this demand. Outdoor rainwater demand for irrigation was critical during lower rainfall periods and high temperatures.

Additionally, to meet the rainwater demand becomes practically unfeasible in cities with a greater seasonality in the rainfall regime and long and low rainfall periods, unless other sources of water, such as the drinking water are used. Otherwise, to meet a reliability that technically and economically justify the RWH use, it would be necessary to considerably increase the storage tank volumes, mainly for small rooftop areas. The use of greater storage volumes could constitute an alternative source of water, especially for places that suffer from shortages during drought periods. In addition, important environmental benefits must be considered, such as the conservation of water sources and reduction of runoff volume, which were not evaluated in this study.

Finally, although the results herein presented reflect the operating conditions of RWH systems evaluated in five Brazilian cities located in different climatic regions, it is recommended that the application of the results is not generalized. Thus, the main findings of this study should be considered as indicative of the need for climate responsive projects of rainwater harvesting systems.

\section{ACKNOWLEDGEMENTS}

This research was supported by the Coordination for the Improvement of Higher Education Personnel - Brazil (CAPES) - Financing Code 001. The authors also thank the continuous support of the Federal University of Santa Maria (Rio Grande do Sul, Brazil) and the Pos-Graduate Program in Civil and Environmental Engineering. 


\section{REFERENCES}

Ali, S., Zhang, S., \& Yue, T. (2020). Environmental and economic assessment of rainwater harvesting systems under five climatic conditions of Pakistan. Journal of Cleaner Production, 259, 1-13. http://dx.doi.org/10.1016/j.jclepro.2020.120829.

Alvares, C. A., Stape, J. L., Sentelhas, P. C., Gonçalves, J. L. M., \& Sparovek, G. (2013). Köppen's climate classification map for Brazil. Meteorologische Zeitschrift, 22(6), 711-728. http://dx.doi. org/10.1127/0941-2948/2013/0507.

Amin, M. T., Kim, T. I., Amin, M. N., \& Han, M. Y. (2013). Effects of catchment, first-flush, storage conditions, and time on microbial quality in rainwater harvesting systems. Water Environment Research, 85(12), 2317-2329. PMid:24597047. http://dx.doi.org/10.2175/ 106143013 X13706200598433.

An, M., Fan, L., Huang, J., Yang, W., Wu, H., Wang, X., \& Khanal, R. (2021). The gap of water supply-Demand and its driving factors: from water footprint view in Huaihe River Basin. PloS One, 16(3), e0247604. PMid:33661966. http://dx.doi.org/10.1371/journal. pone. 0247604 .

Arfanuzzaman, M., \& Rahman, A. A. (2017). Sustainable water demand management in the face of rapid urbanization and ground water depletion for social-ecological resilience building. Global Ecology and Conservation, 10, 9-22. http://dx.doi.org/10.1016/j. gecco.2017.01.005.

Associação Brasileira de Normas Técnicas - ABNT. NBR 15527/2007: aproveitamento de água de chuva de coberturas para fins não potáveis: requisitos. Rio de Janeiro; 2007.

Associação Brasileira de Normas Técnicas - ABNT. NBR 15527/2019: aproveitamento de água de chuva de coberturas para fins não potáveis: requisitos. Rio de Janeiro; 2019.

Basinger, M., Montalto, F., \& Lall, U. (2010). A rainwater harvesting system reliability model based on nonparametric stochastic rainfall generator. Journal of Hydrology, 392(3-4), 105-118. http://dx.doi. org/10.1016/j.jhydrol.2010.07.039.

Brasil. (2020, 16 de julho). Lei no 14.026, de 15 de julho de 2020. Atualiza o marco legal do saneamento básico e dá outras providências. Diário Oficial [da] República Federativa do Brasil, Brasília.

Campisano, A., \& Modica, C. (2012). Optimal sizing of storage tanks for domestic rainwater harvesting in Sicily. Resources, Conservation and Recycling, 63, 9-16. http://dx.doi.org/10.1016/j. resconrec.2012.03.007.

Campisano, A., \& Modica, C. (2014). Selecting time scale resolution to evaluate water saving and retention potential of rainwater harvesting tanks. Procedia Engineering, 70, 218-227. http:/ /dx.doi. org/10.1016/j.proeng.2014.02.025.
Campisano, A., \& Modica, C. (2015). Appropriate resolution timescale to evaluate water saving and retention potential of rainwater harvesting for toilet flushing in single houses. Journal of Hydroinformatics, 17(3), 331-346. http://dx.doi.org/10.2166/ hydro.2015.022.

Campisano, A., \& Modica, C. (2016). Rainwater harvesting as source control option to reduce roof runoff peaks to downstream drainage systems. Journal of Hydroinformatics, 18(1), 23-32. http:/ / dx.doi.org/10.2166/hydro.2015.133.

Campisano, A., Butler, D., Ward, S., Burns, M. J., Friedler, E., DeBusk, K., Fisher-Jeffes, L. N., Ghisi, E., Rahman, A., Furumai, H., \& Han, M. (2017). Urban rainwater harvesting systems: research, implementation and future perspectives. Water Research, 115, 195-209. PMid:28279940. http://dx.doi.org/10.1016/j. watres.2017.02.056.

Cardoso, R. N. C., Blanco, C. J. C., \& Duarte, J. M. (2020). Technical and financial feasibility of rainwater harvesting systems in public buildings in Amazon, Brazil. Journal of Cleaner Production, 260, 1-13. http://dx.doi.org/10.1016/j.jclepro.2020.121054.

Connor, R., Uhlenbrook, S., \& Koncagül, E. (2019). The United Nations world water development report 2019: leaving no one behind, executive summary. Paris: UNESCO Publishing.

Corrêa, J. D. P., Fernandes, L. L., Blanco, C. J. C., \& Neves, R. R. (2018). Proposal of rainwater harvesting coefficient (RWHC) for determination of effectively usable rainfall depth, relevant to rainwater harvesting systems design. RBRH, 23(0), 1-13. http:/ / dx.doi.org/10.1590/2318-0331.231820170109.

Cowden, J. R., Watkins Junior, D. W., \& Mihelcic, J. R. (2008). Stochastic rainfall modeling in West Africa: parsimonious approaches for domestic rainwater harvesting assessment. Journal of Hydrology (Amsterdam), 361(1-2), 64-77. http://dx.doi.org/10.1016/j. jhydrol.2008.07.025.

Dean, A. J., Fielding, K. S., Lindsay, J., Newton, F. J., \& Ross, H. (2016). How social capital influences community support for alternative water sources. Sustainable Cities and Society, 27, 457-466. http://dx.doi.org/10.1016/j.scs.2016.06.016.

Elliott, A. H., \& Trowsdale, S. A. (2007). A review of models for low impact urban stormwater drainage. Environmental Modelling \& Software, 22(3), 394-405. http://dx.doi.org/10.1016/j.envsoft.2005.12.005.

Fewkes, A., \& Butler, D. (2000). Simulating the performance of rainwater collection and reuse systems using behavioural models. Building Services Engineering Research and Technology, 21(2), 99-106. http://dx.doi.org/10.1177/014362440002100204.

Fielding, K. S., Gardner, J., Leviston, Z., \& Price, J. (2015). Comparing public perceptions of alternative water sources for potable use: the case of rainwater, stormwater, desalinated water, and recycled water. Water Resources Management, 29(12), 4501-4518. http://dx.doi.org/10.1007/s11269-015-1072-1. 
Influence of rainfall and design criteria on performance of rainwater harvesting systems placed in different Brazilian climatological conditions

Geraldi, M. S., \& Ghisi, E. (2017). Influence of the length of rainfall time series on rainwater harvesting systems: A case study in Berlin. Resources, Conservation and Recycling, 125, 169-180. http:// dx.doi.org/10.1016/j.resconrec.2017.06.011.

Geraldi, M. S., \& Ghisi, E. (2018). Assessment of the length of rainfall time series for rainwater harvesting in buildings. Resources, Conservation and Recycling, 133, 231-241. http://dx.doi.org/10.1016/j. resconrec.2018.02.007.

Geraldi, M. S., \& Ghisi, E. (2019). Short-term instead of long-term rainfall time series in rainwater harvesting simulation in houses: an assessment using Bayesian Network. Resources, Conservation and Recycling, 144, 1-12. http://dx.doi.org/10.1016/j.resconrec.2019.01.017.

Ghisi, E. (2010). Parameters influencing the sizing of rainwater tanks for use in houses. Water Resources Management, 24(10), 23812403. http://dx.doi.org/10.1007/s11269-009-9557-4.

Ghisi, E., Cardoso, K. A., \& Rupp, R. F. (2012). Short-term versus long-term rainfall time series in the assessment of potable water savings by using rainwater in houses. Journal of Environmental Management, 100, 109-119. PMid:22377369. http://dx.doi. org/10.1016/j.jenvman.2011.12.031.

Helmreich, B., \& Horn, H. (2009). Opportunities in rainwater harvesting. Desalination, 248(1-3), 118-124. http://dx.doi. org/10.1016/j.desal.2008.05.046.

Hentges, S. C. (2013). Efeito de reservatório de aproveitamento de água de chuva sobre redes de drenagem pluvial. (Dissertação de mestrado). Universidade Federal de Santa Maria, Santa Maria.

Herrmann, T., \& Schmida, U. (1999). Rainwater utilization in Germany: efficiency, dimensioning, hydraulic and environmental aspects. Urban Water, 1(4), 307-316. http://dx.doi.org/10.1016/ S1462-0758(00)00024-8.

Hoff, H. (2010). The global water challenge - Modeling green and blue water. Journal of Hydrology (Amsterdam), 384(3-4), 175-176. http://dx.doi.org/10.1016/j.jhydrol.2010.02.027.

Hurlimann, A., \& Dolnicar, S. (2016). Public acceptance and perceptions of alternative water sources: a comparative study in nine locations Public acceptance and perceptions of alternative water sources: a comparative study in nine locations. International Journal of Water Resources Development, 32(4), 650-673. http://dx.doi. org/10.1080/07900627.2016.1143350.

Hurlimann, A. (2011). Household use of and satisfaction with alternative water sources in Victoria Australia. Journal of Environmental Management, 92(10), 2691-2697. PMid:21715083. http://dx.doi. org/10.1016/j.jenvman.2011.06.007.

Immich Júnior, E. G. (2013). Eficácia de sistema de aproveitamento de água da chuva: efeito do tamanho da série de precipitaçoes (Trabalho de conclusão de curso). Universidade Federal do Rio Grande do Sul, Porto Alegre.
Imteaz, M. A., Adeboye, O. B., Rayburg, S., \& Shanableh, A. (2012). Rainwater harvesting potential for southwest Nigeria using daily water balance model. Resources, Conservation and Recycling, 62, 51-55. http://dx.doi.org/10.1016/j.resconrec.2012.02.007.

Imteaz, M. A., Ahsan, A., \& Shanableh, A. (2013). Reliability analysis of rainwater tanks using daily water balance model: variations within a large city. Resources, Conservation and Recycling, 77, 37-43. http://dx.doi.org/10.1016/j.resconrec.2013.05.006.

Instituto Nacional de Meteorologia - INMET. (2016, 12 de março). Recuperado em 1 de março de 2016, de http://www.inmet.gov. br/portal/index.php? $\mathrm{r}=\mathrm{clima} /$ normaisclimatologicas

Jones, M. P., \& Hunt, W. F. (2010). Performance of rainwater harvesting systems in the southeastern United States. Resources, Conservation and Recycling, 54(10), 623-629. http://dx.doi.org/10.1016/j. resconrec.2009.11.002.

Kahinda, J. M., Taigbenu, A. E., \& Boroto, R. J. (2010). Domestic rainwater harvesting as an adaptation measure to climate change in South Africa. Physics and Chemistry of the Earth Parts $A / B / C$, 35(13-14), 742-751. http://dx.doi.org/10.1016/j.pce.2010.07.004.

Kim, J., \& Furumai, H. (2012). Assessment of rainwater availability by building type and water use through GIS-based scenario analysis. Water Resources Management, 26(6), 1499-1511. http:// dx.doi.org/10.1007/s11269-011-9969-9.

Liaw, C., \& Tsai, Y. (2004). Optimum storage volume of rooftop rain water harvesting systems for domestic use 1. Journal of the American Water Resources Association, 40(4), 901-912. http:/ / dx.doi. org/10.1111/j.1752-1688.2004.tb01054.x.

Lopes, V. A., Marques, G. F., Dornelles, F., \& Medellin-Azuara, J. (2017). Performance of rainwater harvesting systems under scenarios of non-potable water demand and roof area typologies using a stochastic approach. Journal of Cleaner Production, 148, 304313. http://dx.doi.org/10.1016/j.jclepro.2017.01.132.

Martínez-Acosta, L., López-Lambraño, A. A., \& López-Ramos, A. (2019). Design criteria for planning the agricultural rainwater harvesting systems: a review. Applied Sciences, 9(24), 1-17. http:/ / dx.doi.org/10.3390/app9245298.

McDonald, R. I., Weber, K., Padowski, J., Flörke, M., Schneider, C., Green, P. A., Gleeson, T., Eckman, S., Lehner, B., Balk, D., Boucher, T., Grill, G., \& Montgomery, M. (2014). Water on an urban planet: urbanization and the reach of urban water infrastructure. Global Environmental Change, 27(1), 96-105. http://dx.doi.org/10.1016/j. gloenvcha.2014.04.022.

Melville-Shreeve, P., Ward, S., \& Butler, D. (2016). Rainwater harvesting typologies for UK houses: a multi criteria analysis of system configurations. Water, 8(7), 129. http://dx.doi.org/10.3390/ w8040129. 
Memon, F. A., Fidar, A., Lobban, A., Djordevic, S., \& Butler, D. (2009). Modelling the effectiveness of rainwater harvesting as a stormwater management option. In Proceedings of the 33rd IAHR Congress. Vancouver: Water Engineering for Sustainable Environment.

Mitchell, V. G., McCarthy, D. T., Deletic, A., \& Fletcher, T. D. (2008). Urban stormwater harvesting: sensitivity of a storage behaviour model. Environmental Modelling \& Software, 23(6), 782-793. http:/ / dx.doi.org/10.1016/j.envsoft.2007.09.006.

Mitchell, V. G. (2007). How important is the selection of computational analysis method to the accuracy of rainwater tank behavior modelling? Hydrological Processes, 21(21), 2850-2861. http:// dx.doi.org/10.1002/hyp.6499.

Mun, J. S., \& Han, M. Y. (2012). Design and operational parameters of a rooftop rainwater harvesting system: definition, sensitivity and verification. Journal of Environmental Management, 93(1), 147-153. PMid:22054581. http://dx.doi.org/10.1016/j.jenvman.2011.08.024.

Muthukumaran, S., Baskaran, K., \& Sexton, N. (2011). Quantification of potable water savings by residential water conservation and reuse: a case study. Resources, Conservation and Recycling, 55(11), 945952. http://dx.doi.org/10.1016/j.resconrec.2011.04.013.

Notaro, V., Liuzzo, L., \& Freni, G. (2016). Reliability analysis of rainwater harvesting systems in Southern Italy. Procedia Engineering, 162, 373-380. http://dx.doi.org/10.1016/j.proeng.2016.11.077.

Pacheco, P. R. C., Gómez, Y. D., Oliveira, I. F., \& Teixeira, L. C. G. (2017). A view of the legislative scenario for rainwater harvesting in Brazil. Journal of Cleaner Production, 141, 290-294. http://dx.doi. org/10.1016/j.jclepro.2016.09.097.

Palla, A., Gnecco, I., \& Lanza, L. G. (2011). Non-dimensional design parameters and performance assessment of rainwater harvesting systems. Journal of Hydrology, 401(1-2), 65-76. http:// dx.doi.org/10.1016/j.jhydrol.2011.02.009.

Palla, A., Gnecco, I., Lanza, L. G., \& La Barbera, P. (2012). Performance analysis of domestic rainwater harvesting systems under various European climate zones. Resources, Conservation and Recycling, 62, 71-80. http://dx.doi.org/10.1016/j.resconrec.2012.02.006.

Perius, C. F. (2016). Variáveis de projeto e sua influência no desempenho e dimensionamento de reservatórios de aproveitamento de água da chuva (Dissertação de mestrado). Universidade Federal de Santa Maria, Santa Maria.

Rahman, A., Keane, J., \& Imteaz, M. A. (2012). Rainwater harvesting in Greater Sydney: water savings, reliability and economic benefits. Resources, Conservation and Recycling, 61, 16-21. http://dx.doi. org/10.1016/j.resconrec.2011.12.002.

Sahin, N. I., \& Manioglu, G. (2019). Water conservation through rainwater harvesting using different building forms in different climatic regions. Sustainable Cities and Society, 44, 367-377. http:/ / dx.doi.org/10.1016/j.scs.2018.10.010.
Sample, D. J., \& Liu, J. (2014). Optimizing rainwater harvesting systems for the dual purposes of water supply and runoff capture. Journal of Cleaner Production, 75, 174-194. http://dx.doi. org/10.1016/j.jclepro.2014.03.075.

Santos, C., \& Taveira-Pinto, F. (2013). Analysis of different criteria to size rainwater storage tanks using detailed methods. Resources, Conservation and Recycling, 71, 1-6. http://dx.doi.org/10.1016/j. resconrec.2012.11.004.

Semaan, M., Day, S. D., Garvin, M., Ramakrishnan, N., \& Pearce, A. (2020). Optimal sizing of rainwater harvesting systems for domestic water usages: a systematic literature review. Resources, Conservation and Recycling, 6, 100033. https://doi.org/10.1016/j. rcrx.2020.100033.

Toosi, A. S., Tousi, E. G., Ghassemi, S. A., Cheshomi, A., \& Alaghmand, S. (2020). A multi-criteria decision analysis approach towards efficient rainwater harvesting. Journal of Hydrology, 582, 124501. http://dx.doi.org/10.1016/j.jhydrol.2019.124501.

U.S. Environmental Protection Agency - US EPA. (2004). EPA report no. 625-R-04-108: guidelines for water use. Washington.

van Dijk, S., Lounsbury, A. W., Hoekstra, A. Y., \& Wang, R. (2020). Strategic design and finance of rainwater harvesting to cost-effectively meet large-scale urban water infrastructure needs. Water Research, 184, 116063. PMid:32717491. http://dx.doi. org/10.1016/j.watres.2020.116063.

Vargas, D., Domingues, I., Ward, S., \& Oviedo-Ocaña, E. R. (2019). Assisting global rainwater harvesting practitioners: a decision support tool for tank sizing method selection under uncertainty. Environmental Science. Water Research \& Technology, 5, 506-520. http:// dx.doi.org/10.1039/c8ew00707a.

Ward, S., Memon, F. A., \& Butler, D. (2010). Rainwater harvesting: model-based design evaluation. Water Science and Technology, 61(1), 85-96. PMid:20057094. http://dx.doi.org/10.2166/wst.2010.783.

World Meteorological Organization - WMO. (1989). Calculation of monthly and annual 30-year standard normal. Geneva: WMO.

Yue, T., Zhang, S., Zhang, J., Zhang, B., \& Li, R. (2020). Variation of representative rainfall time series length for rainwater harvesting modelling in different climatic zones. Journal of Environmental Management, 269, 110731. PMid:32425163. http://dx.doi. org/10.1016/j.jenvman.2020.110731.

Zhang, S., Jing, X., Yue, T., \& Wang, J. (2020). Performance assessment of rainwater harvesting systems: influence of operating algorithm, length and temporal scale of rainfall time series. Journal of Cleaner Production, 253, 1-13. http://dx.doi.org/10.1016/j. jclepro.2020.120044.

Zhang, S., Zhang, J., Yue, T., \& Jing, X. (2019). Impacts of climate change on urban rainwater harvesting systems. The Science of the Total Environment, 665, 262-274. PMid:30772557. http://dx.doi. org/10.1016/j.scitotenv.2019.02.135. 
Influence of rainfall and design criteria on performance of rainwater harvesting systems placed in different Brazilian climatological conditions

\section{Authors contributions}

Carla Fernanda Perius: Bibliographical research, performed the methodology, data analysis, discussion and interpretation of the results, writing.

Rutineia Tassi: Defined the objectives, discussion and interpretation of the results, manuscript writing and review, and study supervision.

Lucas Alves Lamberti: Complemented the methodology, complemented the data analysis and discussion, and performed the illustrations.
Angélica Guimarães da Silva: Complemented the data analysis and discussion, illustrations, contributed with bibliographical research and discussion.

Liriane Élen Böck: Complemented the data analysis and discussion, illustrations, contributed with bibliographical research and discussion.

Editor-in-Chief: Adilson Pinheiro

Associated Editor: Priscilla Macedo Moura 